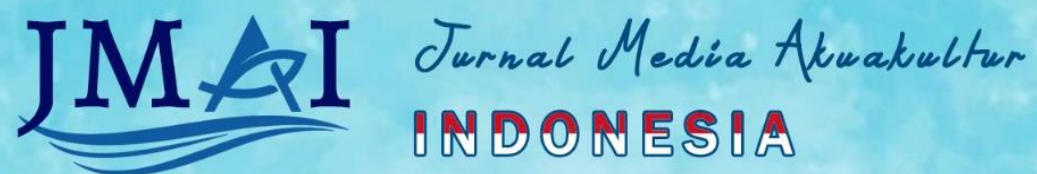

https://journal.unram.ac.id/index.php/jmai/index. E-ISSN : 2798-0553

VOLUME 1, NOMOR 1, JUNI 2021

\title{
PERTUMBUHAN CAULERPA sp. YANG DIBUDIDAYAKAN DENGAN METODE LONGLINE DIDESA ROMPO KECAMATAN LANGGUDU KABUPATEN BIMA
}

\author{
GROWTH OF CAULERPA sp. CULTIVATED WITH THE LONGLINE METHOD IN ROMPO \\ VILLAGE, LANGGUDU DISTRICT, BIMA REGENCY
}

Sinta Rahmawati, Muhammad Junaidi, Nunik Cokrowati*)

Program Studi Budidaya Perairan, Fakultas Pertanian, Universitas Mataram

JL. Pendidikan No. 37 Mataram Nusa Tenggara Barat

Alamat korespondensi : nunikcokrowati@unram.ac.id

\begin{abstract}
ABSTRAK
Makroalga yang ada di Indonesia dan potensial di budidayakan selain jenis Glacilaria sp. dan Eucheuma sp. adalah rumput laut jenis Caulerpa sp. Tujuan penelitian ini adalah untuk mengetahui pengaruh jarak tanam dan kedalaman berbeda terhadap pertumbuhan dan antioksidan Caulerpa sp. yang dibudidayakan dengan metode longline. Penelitian dilaksanakan di perairan Desa Rompo Kecamatan Langgudu Kabupaten Bima Nusa Tenggara Barat. Metode penelitian adalah Rancangan Acak Lengkap (RAL) faktorial dengan dua faktor. Faktor pertama adalah jarak tanam terdiri dari 3 perlakuan. Faktor kedua adalah kedalaman terdiri dari 2 perlakuan. Kombunasi jarak dengan kedalaman pada penelitian ini adalah ; A : jarak tanam 20 $\mathrm{cm}$ - kedalaman $50 \mathrm{~cm}, \mathrm{~B}$ : jarak tanam $30 \mathrm{~cm}$ - kedalaman $50 \mathrm{~cm}, \mathrm{C}$ : jarak tanam $40 \mathrm{~cm}$ kedalaman $50 \mathrm{~cm}, \mathrm{D}$ : jarak tanam $20 \mathrm{~cm}$ - kedalaman $100 \mathrm{~cm}$, E : jarak tanam $30 \mathrm{~cm}$ - kedalaman $100 \mathrm{~cm}$ dan $\mathrm{F}$ : jarak tanam $40 \mathrm{~cm}$ - kedalaman $100 \mathrm{~cm}$. Hasil penelitian menunjukkan bahwa jarak tanam yang berbeda memberikan pengaruh yang signifikan taraf $5 \%$ terhadap pertumbuhan Caulerpa sp. dan tidak ada interaksi antara faktor JT (Jarak Tanam) dengan Faktor KD (Kedalaman) terhadap laju pertumbuhan mutlak Caulerpa sp. Laju pertumbuhan mutlak Caulerpa sp. terbaik diperoleh dari perlakuan jarak tanam $30 \mathrm{~cm}$ dengan kedalaman 50 $\mathrm{cm}$ yaitu $111 \pm 27$ gram dengan laju pertumbuhan spesifik sebesar $2,477 \pm 412^{\mathrm{b}} \% /$ hari. Kandungan antioksidan tertinggi diperoleh pada jarak tanam $40 \mathrm{~cm}$ dengan kedalaman $50 \mathrm{~cm}$ sebesar $45,57 \%$. Kesimpulan penelitian ini adalah interaksi antara faktor jarak tanam dengan faktor kedalaman tidak berpengaruh terhadap pertumbuhan mutlak dan pertumbuhan spesifik Caulerpa sp. Kedalaman yang berbeda memberikan pengaruh yang nyata terhadap kandungan antioksidan Caulerpa sp.
\end{abstract}

Kata Kunci Rumput laut, anggur laut, jarak tanam, kedalaman, antioksidan

Tracebility Tanggal diterima : 20 Mei 2021. Tanggal publikasi : 23 Juni 2021

Panduan

Kutipan

(APPA $7^{\text {th }}$ )
Rahmawanti, S., Junaidi, M., \& Cokrowati, N. (2021). Pertumbuhan Caulerpa sp. Yang Dibudidayakan Dengan Metode Longline di Desa Rompo Kecamatan Langgudu Kabupaten Bima. Jurnal Media Akuakultur Indonesia, 1 (1), 2134. http://doi.org/10.29303/mediaakuakultur.v1i1.137 


\section{PENDAHULUAN}

Indonesia sebagai negara maritim mempunyai prospek yang cukup cerah untuk mengembangkan dan memberdayakan sumber hayati kelautan. Salah satu komponen biota yang merupakan sumber daya hayati kelautan adalah makroalga. Makroalga yang umum dijumpai di laut terkenal pula dengan nama rumput laut. Salah satu jenis rumput laut yang potensial di budidayakan selain jenis Glacilaria sp. dan Eucheuma sp. adalah rumput laut jenis Caulerpa sp. Rumput laut jenis ini banyak di gemari baik masyarakat dalam negeri maupun luar negeri seperti Jepang, China dan Philipina karena mempunyai nilai ekonomis yang sangat penting sebagai bahan makanan segar dan bahan untuk obt-obatan (Susilowati et al., 2017) Caulerpa merupakan salah satu spesies dari Chlorophyceae (ganggang hijau) mempunyai pigmen fotosintetik yaitu klorofil a dan b dengan jumlah yang melimpah yang dapat berfungsi sebagai antioksidan. Antioksidan adalah senyawa yang dapat mencegah proses oksidasi radikal bebas karena mengandung asam folat, tiamin, dan asam askorbat (Fatmawati et al., 2019).

Potensi rumput laut jenis Caulerpa sudah banyak dikembangkan dan dibudidayakan di masyarakat, mengingat rumput laut jenis Caulerpa ini memiliki banyak manfaat yang sangat beraneka ragam antara lain dapat mengobati atau mencegah kanker, membantu menurunkan kadar kolesterol dan dapat berfungsi membuang zat-zat beracun dalam tubuh. Saat ini cara memperoleh Caulerpa hanya berdasarkan pada hasil ekstraktif atau hanya mengumpulkan secara langsung dari pinggir pantai. Sehingga sangat potensial untuk dikembangkan dan dibudidayakan (Noor Mahmudah \& Juli Nursandi, 2014).

Caulerpa banyak dijumpai pada tempat yang terlindungi dengan air yang jernih. Aliran air tidak terlalu kuat arusnya dan bagian dasar halus karena adanya sedimentasi. Keanekaragaman Caulerpa paling tinggi di daerah tropik yaitu di zona culitoral dan berkurang pada zona bagian dalam. Pada zona sublitoral Caulerpa tumbuh menempel pada karang atau merayap di bawah kanopi coral Prod'homme Van Reine dan Trono (2011) dalam (Saptasari, 2012).

Sebaran jenis Caulerpa sp. cukup luas terutama pada kawasan beriklim tropis karena jenis ini membutuhkan asupan sinar matahari dalam proses fotosintesisnya. Jenis Caulerpa sp. dijumpai disebagian besar wilayah asia yakni, Indonesia, Thailand, Malaysia, Jrpang, China, Filipina, Korea, serta lokasi lain yang sekitar kawasan asia. Sebaran jenis Caulerpa sp. juga di jumpai di pulau-pulau kecil di Indonesia serta Nusa Tenggara (Razai et al., 2019).

Budidaya Caulerpa sp. sudah mulai dikembangkan di Indonesia seperti di pulau jawa, masyarakat memanfaatkan anggur laut sebagai penetral kualitas air pada tambak udang, sementara itu di wilayah NTB sendiri masih belum ada yang mulai membudidayakannya. Kegiatan budidaya belum dimanfaatkan karena masih mengandalkan penangkapan dari alam. Selain itu, budidaya anggur laut tergolong baru, sehingga masyarakat belum mengetahui bobot bibit yang sesuai kriteria, kedalaman, metode budidaya yang diterapkan, kontrol selama proses produksi dan jarak tanam yang 
digunakan dalam kegiatan budidaya (Iskandar et al., 2017) Perbedaan kedalaman perairan menyebabkan intensitas cahaya matahari bervariasi pada zona perairan sehingga laju fotosintesis rumput laut akan berbeda. Jarak tanam bibit mempengaruhi pergerakan air yang membawa unsur hara bagi rumput laut (Darmawati et al., 2016). Peningkatan proses fotosintesis akan menyebabkan proses metabolisme sehingga merangsang rumput laut untuk menyerap unsur hara yang lebih banyak untuk tumbuh. Oleh karena itu, maka sangat penting dilakukannya penelitian tentang pengaruh jarak tanam dan kedalaman berbeda pada Caulerpa sp. dengan metode longline sehingga nantinya dapat menjadi bahan informasi dan pengetahuan untuk para pembudidaya yang melakukan budidaya anggur laut

\section{METODE PENELITIAN}

Kegiatan ini dilaksanakan selama 30 hari. Bertempat di Desa Rompo, Kecamatan Langgudu, Kabupaten Bima. Analisis kandungan antioksidan telah dilakukan di Laboratorium Kimia Analitik, Fakultas Matematika dan Ilmu Pengetahuan Alam, Universitas Mataram.

Adapun alat dan bahan yang digunakan pada penelitian ini adalah timbangan, alat tulis, thermometer, pH meter, refraktometer, tali raffia, talis ris, batu, emebr, aquades, kamera, nitrit kit, nitrat kit, fosfat kit, tissue dan Caulerpa

Metode Penelitian ini menggunakan Rancangan Acak Lengkap (RAL) faktorial dengan dua faktor. Faktor pertama adalah jarak tanam terdiri dari 3 taraf perlakuan. Faktor kedua adalah kedalaman terdiri dari 2 taraf perlakuan. Perlakuan dalam penelitian ini adalah hasil kombinasi antar faktor dari seluruh taraf perlakuan. Dengan demikian, dalam penelitian ini terdapat 3x2 kombinasi atau 6 kombinasi.

Tabel 1. Perlakuan yang diterapkan pada jarak tanam dan kedalaman yang berbeda.

\begin{tabular}{ccc}
\hline & \multicolumn{2}{c}{ Perlakuan } \\
\hline $\begin{array}{c}\text { Jarak Tanam } \\
\text { (JT) }\end{array}$ & \multicolumn{2}{c}{$\begin{array}{c}\text { Kedalaman } \\
(\text { KD) }\end{array}$} \\
\cline { 2 - 3 } & $50 \mathrm{~cm} \mathrm{(KD1)}$ & $100 \mathrm{~cm}$ \\
& & KD2) \\
\hline $20 \mathrm{~cm}$ & JT1KD1 & JT1KD2 \\
$30 \mathrm{~cm}$ & JT2KD1 & JT2KD2 \\
$40 \mathrm{~cm}$ & JT3KD1 & JT3KD2 \\
\hline
\end{tabular}




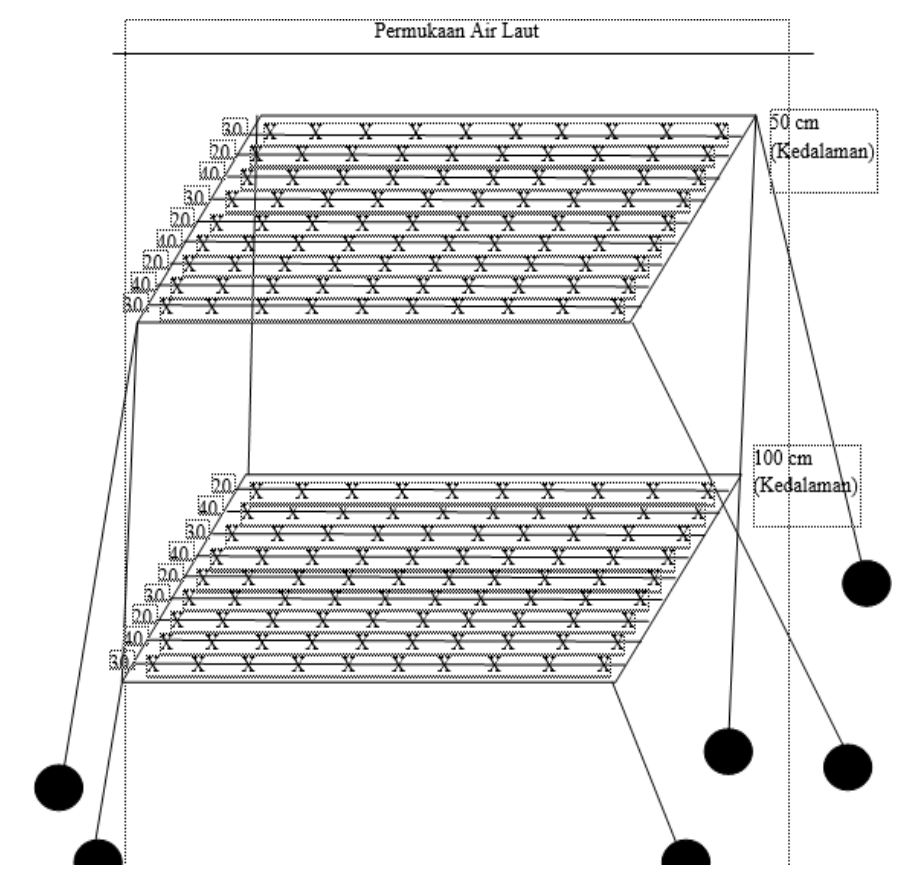

Gambar 1. Tata Letak Unit Percobaan

Tahapan penelitian yang dilakukan yaitu tahap persiapan longline dengan menyiapkan alat dan bahan yang akan digunakan untuk membuat longline sebagai

kontruksibudidaya. Dibuat longline dari tali polietilen $10 \mathrm{~mm}$ dengan panjang $11 \mathrm{~m}$ dan lebar $3 \mathrm{~m}$. Didalam longline terdapat 4 tali ris dengan jarak antar tali $50 \mathrm{~cm}$. Diletakkan longline ditempat yang sudah ditentukan lokasinya dengan kedalaman 50 $\mathrm{cm}$ dan $100 \mathrm{~cm}$ pada saat surut terendah. Panjang longline yang digunakan berukuran $5 \times 5$ meter. Tahap persiapan bibit Caulerpa yaitu bibit anggur laut yang digunakan adalah bibit yang langsung diambil darialam. Bibit anggur laut ditimbang dengan berat bibit awal yang sama yaitu berat 100 gram. Diikatkan bibit pada tali ris menggunakan tali rafiah dengan jarak antar bibit yaitu $20 \mathrm{~cm}, 30 \mathrm{~cm}$, dan $40 \mathrm{~cm}$. Tali ris yang digunakan sepanjang $11 \mathrm{~m}$. Didalam longline jarak antar tali ris masing-masing $20 \mathrm{~cm}$, $30 \mathrm{~cm}$ dan $40 \mathrm{~cm}$ diletakkan dengan perlakuan kedalaman $50 \mathrm{~cm}$ dan $100 \mathrm{~cm}$. Tahap penanaman Caulerpa yaitu diambil bibit anggur laut yang sudah ditimbang tadi sebanyak 100 gram. diikat pada tali dengan jarak $20 \mathrm{~cm}, 30 \mathrm{~cm}$, dan $40 \mathrm{~cm}$ dengan panjang tali 11 meter direntangkan pada kayu yang digunakan sebagai pemberat dan petanda untuk sampel budidaya. Tahap pemeliharaan Caulerpa yaitu Selama anggur laut (Caulerpa) berada di wadah budidaya, selama itu pula beberapa kegiatan terus dilakukan untuk memastikan anggur laut (Caulerpa) dalam kondisi baik. Beberapa kegiatan yang secara rutin dilakukan adalah mengontrol tanaman, membersihkan lumpur, dan melakukan pemeriksaan apakah ada Caulerpa yang rusak atau mati.Terakhir tahap pengamatan pertumbuhan yaitu diambil sampel Caulerpa sp. pada setiap perlakuan yaitu pada perlakuanjarak tanam (J1, J2, dan J3) dan pada perlakuan perbedaan kedalaman (KD1 dan KD2). ditimbang Caulerpa sp. pada setiap perlakuan 
pada waktu yang telah ditentukan pada hari ke- 0, 10, 20 dan 30. dilakukan uji antioksidan pada Caulerpa sp.

Parameter yang digunakan untuk menguji hasil penelitian meliputi:

1. Laju Pertumbuhan Mutlak

Menurut Kasim et al., (2017), pertumbuhan mutlak dapat diukur menggunakan rumus pertumbuhan mutlak adalah sebagai berikut:

$\mathrm{G}=\mathrm{Wt}-\mathrm{Wo}$

Keterangan:

$\mathrm{G}=$ Pertumbuhan mutlak rata-rata (gr)

$\mathrm{Wt}=$ Berat bibit pada akhir penelitian (gr)

Wo = Berat bibit pada awal penelitian (gr)

2. Laju Pertumbuhan Spesifik

Menurut Kasim et al., (2017), pertumbuhan spesifik dapat diukur menggunakan rumus pertumbuhan spesifik adalah sebagai berikut:

$$
S G R=\frac{(\operatorname{Ln} W t-\operatorname{Ln} W o)}{t} \times 100 \%
$$

Keterangan:

SGR = Laju pertumbuhan harian spesifik (\%/hari)

$\mathrm{Wt} \quad=$ Berat rata-rata ikan pada akhir penelitian (gr/ekor)

Wo = Berat rata-rata ikan awal penelitian (gr/ekor)

$\mathrm{t} \quad=$ Waktu (lama pemeliharaan)

3. Jumlah Bulatan Thalus

Untuk menghitung jumlah bulatan pada Caulerpa sp. dilakukan dengan menghitung jumlah bulatan yang berada pada thalus dengan waktu yang telah ditentukan yaitu pada hari ke - 0, 10, 20, dan 30 .

\section{Kualitas Air}

Data kualitas air merupakan data pendukung yang meliputi suhu, salinitas, $\mathrm{pH}$, kecepatan arus, nitrat, fosfat dan oksigen terlarut (DO). Pengambilan sampel kualitas air dilakukan satu kali dalam 10 hari pada pagi hari.

\section{Analisis Antioksidan}

Menurut (Molyneux, 2004 dalam Rahmawati, 2016) aktivitas antioksidan sampel ditentukan oleh besarnya hambatan serapan radikal DPPH melalui perhitungan persentase (\%) inhibisi serapan DPPH dengan menggunakan rumus sebagai berikut:

$\%$ inhibisi $=\frac{(\text { Absorban blanko }- \text { Absorban sampel })}{\text { Absorban blanko }} \times 100 \%$ 
Keterangan:

$\%$ inhibisi $=$ Tingkat inhibisi

Absorban blanko = Serapan radikal DPPH

Absorban sampel = Serapan sampel dalam radikal DPPH

Data-data dari hasil penelitian ini adalah data pertumbuhan mutlak dan pertumbuhan relatif serta analisis kandungan antioksidan. Untuk mengetahui pengaruh perlakuan yang diberikan menggunakan analisis ragam (ANNOVA), selanjutnya dilakukan uji wilayah ganda Duncan untuk mengetahui perbedaan tiap perlakuan.

\section{HASIL DAN PEMBAHASAN}

1. Laju Pertumbuhan Mutlak

Tabel 2. Laju Pertumbuhan Mutlak Caulerpa sp. (g)

\begin{tabular}{ccccccc}
\hline \multicolumn{2}{c}{ Perlakuan } & \multicolumn{5}{c}{ Ulangan } \\
\hline $\begin{array}{c}\mathrm{JT} \\
(\mathrm{cm})\end{array}$ & KD $(\mathrm{cm})$ & 1 & 2 & 3 & $\begin{array}{c}\text { Rata- } \\
\text { rata }\end{array}$ & $\begin{array}{c}\text { Rerata } \pm S \\
\text { D }\end{array}$ \\
\hline 20 & 50 & 67 & 68 & 45 & 180 & $60 \pm 13^{\mathrm{a}}$ \\
20 & 100 & 75 & 29 & 41 & 145 & $48 \pm 24^{\mathrm{a}}$ \\
30 & 50 & 100 & 142 & 92 & 339 & $111 \pm 27^{\mathrm{b}}$ \\
30 & 100 & 85 & 96 & 101 & 282 & $94 \pm 8^{\mathrm{b}}$ \\
40 & 50 & 72 & 69 & 51 & 192 & $64 \pm 11^{\mathrm{a}}$ \\
40 & 100 & 62 & 41 & 45 & 148 & $49 \pm 11^{\mathrm{a}}$ \\
\hline
\end{tabular}

Keterangan = huruf yang tidak sama menunjukkan perbedaan sangat nyata antar perlakuanpada taraf $5 \%$.

2. Laju Pertumbuhan Spesifik

Tabel 3. Laju Pertumbuhan Spesifik

\begin{tabular}{ccccccc}
\hline \multicolumn{3}{c}{ Perlakuan } & \multicolumn{5}{c}{ Ulangan } \\
\hline $\begin{array}{c}\mathrm{JT} \\
(\mathrm{cm})\end{array}$ & $\begin{array}{c}\text { KD } \\
(\mathrm{cm})\end{array}$ & 1 & 2 & 3 & $\begin{array}{c}\text { Rata- } \\
\text { rata }\end{array}$ & Rerata \pm SD \\
\hline 20 & 50 & 1,709 & 1,729 & 1,239 & 4,677 & $1,559 \pm 0,278^{\mathrm{a}}$ \\
20 & 100 & 1,865 & 0,849 & 1,145 & 7,431 & $1,286 \pm 0,412^{\mathrm{a}}$ \\
30 & 50 & 2,31 & 2,946 & 2,174 & 4,931 & $2,477 \pm 0,235^{\mathrm{b}}$ \\
30 & 100 & 2,051 & 2,243 & 2,327 & 3,859 & $2,207 \pm 0,523^{\mathrm{b}}$ \\
40 & 50 & 1,808 & 1,749 & 1,374 & 6,621 & $1,644 \pm 0,142^{\mathrm{a}}$ \\
40 & 100 & 1,608 & 1,145 & 1,239 & 3,992 & $1,331 \pm 0,245^{\mathrm{a}}$ \\
\hline
\end{tabular}

Keterangan = huruf yang tidak sama menunjukkan perbedaan sangat nyata antar perlakuanpada taraf $5 \%$. 
3. Jumlah Bulatan Caulerpa

Tabel 4. Jumlah Bulatan Caulerpa

\begin{tabular}{ccccccc}
\hline \multicolumn{6}{c}{ Perlakuan } & \multicolumn{5}{c}{ Ulangan } \\
\hline $\begin{array}{c}\mathrm{JT} \\
(\mathrm{cm})\end{array}$ & $\begin{array}{c}\text { KD } \\
(\mathrm{cm})\end{array}$ & 1 & 2 & 3 & Rata-rata \\
\hline 20 & 50 & 818 & 823,2 & 818,5 & 819,917 & $\mathrm{ab}$ \\
& & & 5 & & & \\
20 & 100 & 928 & 922,7 & 926,5 & 930,833 & $\mathrm{a}$ \\
& & & 5 & & & \\
30 & 50 & 1010 & 779,5 & 1003 & 906,917 & $\mathrm{a}$ \\
30 & 100 & 926 & 932 & 933,25 & 925,750 & $\mathrm{a}$ \\
40 & 50 & 890,5 & 897 & 933,25 & 930,417 & $\mathrm{a}$ \\
40 & 100 & 702,2 & 721,2 & 732,5 & 718,667 & $\mathrm{~b}$ \\
& \multicolumn{70}{c}{} & 5 & 5 & & & \\
\hline
\end{tabular}

Nilai BNJ = 150, 140

Keterangan = huruf yang tidak sama menunjukkan perbedaan sangat nyata antar perlakuanpada taraf $5 \%$.

4. Analisis Antioksidan

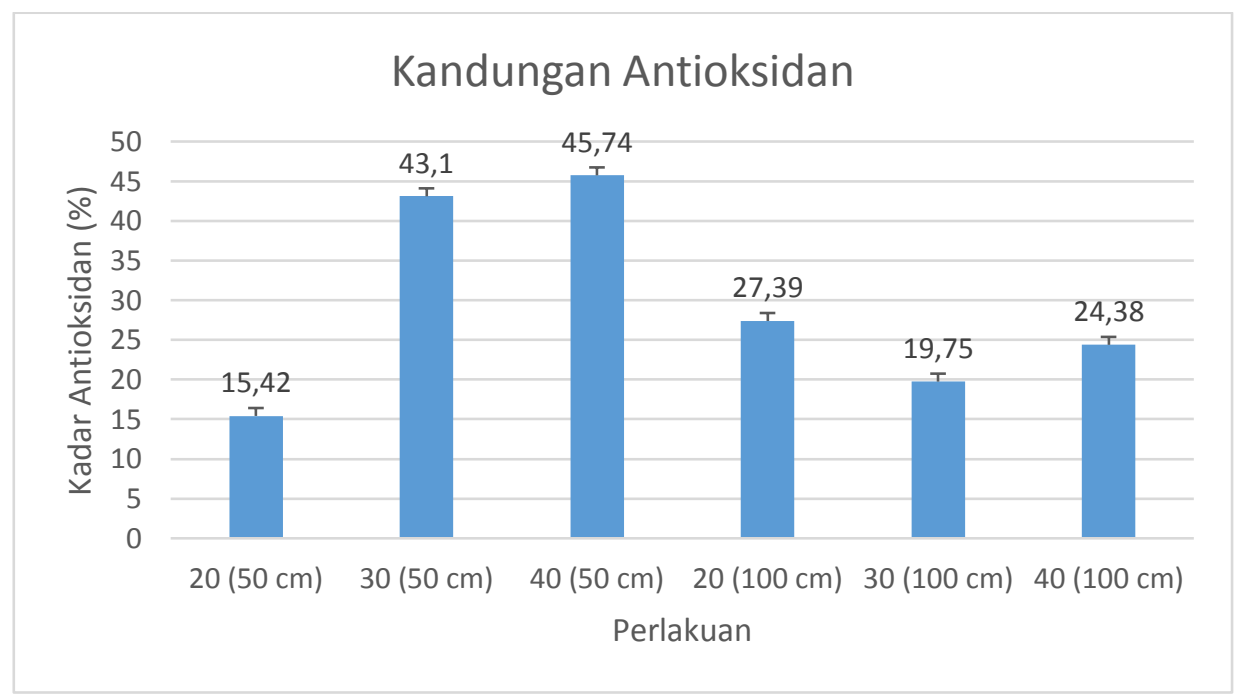

Gambar 2. Kandungan Antioksidan 
5. Kualitas Air

Tabel 5. Pengukuran Kualitas Air

\begin{tabular}{|c|c|c|c|c|}
\hline No & Parameter & $\begin{array}{c}\text { Hasil } \\
\text { Lingkungan }\end{array}$ & $\begin{array}{l}\text { Kisaran } \\
\text { Kualitas Air }\end{array}$ & Sumber Pustaka \\
\hline 1. & Salinitas & $28-29 \mathrm{ppt}$ & $\begin{array}{l}\text { 22-34 ppt dan } \\
30-34 \text { ppt }\end{array}$ & Fatmawati (2019) \\
\hline 2. & Suhu & $27,4-27,5^{\circ} \mathrm{C}$ & $20-30^{\circ} \mathrm{C}$ & Dahlia \& Rejeki (2017) \\
\hline 3. & $\mathrm{pH}$ & $7,7-7,8$ & $6,5-8,5$ & Fatmawati (2019) \\
\hline 4. & $\begin{array}{l}\text { Nitrit } \\
(\mathrm{mg} / \mathrm{l})\end{array}$ & 0,05 & $0,001 \mathrm{mg} / \mathrm{l}$ & Putri (2019) \\
\hline 5. & $\begin{array}{l}\text { Fosfat } \\
(\mathrm{mg} / \mathrm{l})\end{array}$ & 0,1 & $0,1 \mathrm{ppm}$ & Darmawati (2016 \\
\hline 6. & $\begin{array}{l}\text { Kecapatan } \\
\text { Arus }\end{array}$ & $2,31-3,70 \mathrm{~m} / \mathrm{s}$ & $40-50 \mathrm{~cm} / \mathrm{s}$ & Novianti (2015) \\
\hline 7. & $\begin{array}{l}\text { Nitrat } \\
(\mathrm{mg} / \mathrm{l})\end{array}$ & 10 & $0,09-3,5 \mathrm{mg} / \mathrm{l}$ & Suparjo (2008) \\
\hline
\end{tabular}

1. Laju Pertumbuhan Mutlak

Hasil budidaya yang dilakukan selama 30 hari dengan menggunakan 3 perlakuan jarak tanam dan 2 perlakuan kedalaman untuk pertumbuhan rumput laut Caulerpa sp. terbaik dengan pengaruh jarak tanam dan kedalaman berbeda dan didapatkan hasil bahwa pada jarak tanam berbeda mempengaruhi pertumbuhan mutlak secara signifikan dengan taraf 5\%. Sedangkan faktor kedalaman tidak dapat memberikan pengaruh yang signifikan terhadap pertumbuhan Caulerpa sp. dan tidak terjadi interaksi antara faktor jarak tanam dan faktor kedalaman terhadap pertumbuhan mutlak Caulerpa sp.

Berdasarkan hasil penelitian selama 30 hari pemeliharaan dapat dilihat pada (Tabel 6), terlihat bahwa pertumbuhan mutlak Caulerpa sp tertinggi terdapat pada perlakuan jarak tanam $30 \mathrm{~cm}$ dengan kedalaman $50 \mathrm{~cm}$ dengan nilai pertumbuhan mutlak sebesar $111 \pm 27^{\mathrm{b}}$ gram dan yang terendah pada perlakuan jarak tanam $20 \mathrm{~cm}$

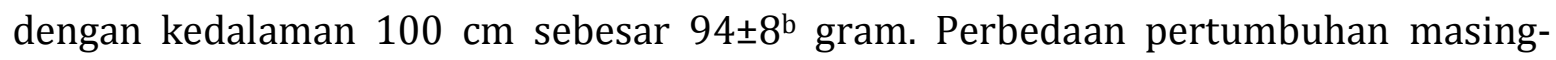
masing perlakuan menunjukkan bahwa rumput laut Caulerpa sp. Melakukan mekanisme adaptasi terhadap lingkungan terutama terhadap cahaya yang berbeda pada kedalaman yang berbeda. Disamping itu,adaptasi terhadap faktor lain seperti kecepatan arus, nutrien terlarut dan suhu yang berkaitan dengan pertumbuhan thallus. Walaupun kedalaman tidak berpengaruh secara signifikan terhadap pertumbuhan Caulerpa tetapi peranan kedalaman dibutuhkan untuk pertumbuhan Caulerpa, seperti yang diketahui bahwa Rumput laut Caulerpa sebagaimana tanaman khorofil lainnya memerlukan unsur hara sebagai bahan baku untuk proses fotosintesis bagi pertumbuhannya. Kecukupan sinar matahari sangat menentukan kecepatan rumput laut untuk memenuhi kebutuhan nutrien seperti nitrogen $(\mathrm{N})$ dan fosfor $(\mathrm{P})$ untuk pertumbuhan dan pembelahan selnya. Selain karena penyerapan unsur hara, metode yang digunakan juga dapat mempengaruhi pertumbuhan rumput laut. Metode long line 
merupakan metode yang dilakukan dipermukaan perairan dimana terdapat intensitas cahaya yang tinggi. Seperti yang dikemukakan oleh Azizzah (2006), bahwa rumput laut merupakan tumbuhan berkhorofil yang memerlukan sinar matahari untuk pertumbuhannya, sehingga untuk pertumbuhannya rumput laut hanya terbatas pada tempat yang dangkal saja. Hal ini juga diperkuat oleh pernyatan dari Susilowati (2012), yang menyatakan bahwa laju pertumbuhan yang kurang maksimal disebabkan oleh adanya ketersediaan intensitas cahaya yang masuk kedalam perairan kurang.

Dalam penelitian ini, tingginya pertumbuhan mutlak pada perlakuan jarak tanam $30 \mathrm{~cm}$, hal ini disebabkan pada jarak tanam $30 \mathrm{~cm}$ secara nyata mempengaruhi pertumbuhan rumput laut dari aspek suplai nutrien yang didapatkan oleh rumput laut. Nutrien yangdibutuhkan oleh rumput laut dalam pertumbuhannya seperti nitrat, dan fosfat. Hal ini sesuai pernyataan Darmawati (2015), bahwa jarak tanam rumput laut dapat mempengaruhi persaingan dalam mendapatkan unsur hara atau nutrien. Jarak tanam berhubungan dengan lalu lintas pergerakan air yang membawa unsur hara dan fisika kimia air lainnya baik secara horizontal maupun vertikal. Hal ini menyebabkan lebih efektif untuk proses pertumbuhannya. Kondisi ini sangat mendukung pertumbuhan rumput laut yang dibudidayakan.

Dari hasil Univariate Analysis of Variance (ANOVA) menunjukkan bahwa pengaruh jarak tanam berbeda memberikan pengaruh yang signifikan pada pertumbuhan Caulerpa sp., karena terdapat perbedaan yang nyata sehingga dilakukan uji lanjut Tukey/BNJ untuk melihat pengaruh antar perlakuan. Uji lanjut Tukey/BNJ pada perlakuan jarak tanam 20 dan $40 \mathrm{~cm}$ dengan kedalaman $50 \mathrm{~cm}$ dan $100 \mathrm{~cm}$ tidak memberikan pengaruh yang berbeda nyata terhadap pertumbuhan Caulerpa, tetapi pada perlakuan jarak tanam $30 \mathrm{~cm}$ dengan kedalaman $50 \mathrm{~cm}$ dan $100 \mathrm{~cm}$ memberikan pengaruh yang berbeda nyata untukpertumbuhan Caulerpa sp. Menurut Prihaningrum et al., (2011), bahwa jarak tanam bibit mempengaruhi pergerakan air yang membawa unsur hara bagi rumput laut. Berdasarkan uji yang telah dilakukan untuk pertumbuhan mutlak didapatkan hasil yang berbeda nyata pada perlakuan jarak tanam yang berbeda. Hal ini diperkuat oleh Darmawati (2017), bahwa jarak tanam akan mempengaruhi lalu lintas pergerakan air dan akan menghindari terkumpulnya kotoran pada thallus yang akan membantu pengudaraan sehingga proses fotosintesis yang diperlukan untuk pertumbuhan rumput laut dapat berlangsung serta mencegah adanya fluktuasi yang besar terhadap salinitas maupun suhu. Ardiansyah (2020) juga menyatakan bahwa pertumbuhan rumput laut dipengaruhi oleh jarak bibit.

\section{Pertumbuhan Spesifik}

Hasil Anova menunjukkan bahwa hanya perlakuan jarak tanam yang memberikan pengaruh terhadap laju pertumbuhan spesifik Caulerpa sp. Sedangkan faktor kedalaman tidak dapat memberikan pengaruh yang signifikan terhadap pertumbuhan Caulerpa sp. dan tidak terjadi interaksi antara faktor jarak tanam dan faktor kedalaman terhadap pertumbuhan mutlak Caulerpa sp.

Hasil rerata nilai pertumbuhan spesifik Caulerpa sp. terbaik selama 30 hari dicapai oleh perlakuan jarak tanam $30 \mathrm{~cm}$ dengan perlakuan kedalaman $50 \mathrm{~cm}$ dimana 
nilai rerata laju pertumbuhan spesifik $=2,477 \pm 0,235^{\mathrm{b}} \% /$ hari. Sedangkan pertumbuhan terendah pada perlakuan jarak tanam $20 \mathrm{~cm}$ dengan perlakuan kedalaman $100 \mathrm{~cm}$, dimana nilai rerata laju pertumbuhan spesifik $=1,286 \pm 0,412^{\text {a }} \% /$ hari. Pada perlakuan jarak tanam $20 \mathrm{~cm}$ pertumbuhannya yang paling rendah dibandingkan dengan perlakuan jarak tanam yang lainnya ini disebabkan karenakan jarak tanam $20 \mathrm{~cm}$ pada masa pemeliharaan thallus rumput laut saling terkait sehingga menganggu lalu lintas air yang membawa nutrien yang dibutuhkan oleh rumput laut, selain itu rumput laut pada jarak tanam $20 \mathrm{~cm}$ banyak dijumpai tumbuhan mikro (lumut) yang menempel sehingga menganggu pertumbuhan dari rumput laut akibat saling berebut nutrien dengan tumbuhan lumut. Hal ini didukung oleh pendapat Anggadireja (2006), bahwa tumbuhan sekitar tanaman budidaya menganggu pertumbuhan rumput laut. Penurunan pertumbuhan rumput laut pada jarak tanam $20 \mathrm{~cm}$ dikarenakan thallus rumput laut berhimpitan dan mengakibatkan kurangnya pasokan sinar matahari yang dibutuhkan untuk proses fotosintesis. Masyahoro danMappiratu (2009) menyatakan bahwa jarak tanam rumput laut mempengaruhi luasan thallus rumput laut yang terpapar sinar matahari sehingga secara tidak langsung akan berpengaruh pula terhadap proses fotosintesis yang mendukung dalam pertumbuhan rumput laut. Jarak tanam yang berbeda memberikan pengaruh yang sangat signifikan pada pertumbuhan Caulerpa sp., karena terdapat perbedaan yang nyata sehingga dilakukan uji lanjut Tukey/BNJ untuk melihat pengaruh antar perlakuan. Hasil uji lanjut menunjukkan bahwa pada perlakuan jarak tanam $20 \mathrm{~cm}$ dan $40 \mathrm{~cm}$ dengan kedalaman $50 \mathrm{~cm}$ dan 100 cm tidakmemberikan pengaruh yang berbeda nyata terhadap pertumbuhan Caulerpa sp., akan tetapi yang dapat memberikan pengaruh yang berbeda nyata hanya pada perlakuan jarak tanam $30 \mathrm{~cm}$ dengan kedalaman $50 \mathrm{~cm}$ dan 100 untuk pertumbuhan Caulerpa. Hal ini sesuaipernyataan dari Darmawati (2016), bahwa jarak tanam dapat mempengaruhi pergerakan air yang membawa unsur hara sehingga pertumbuhan Caulerpa racemosa. meningkat, danmenurut. Walaupun kedalaman tidak berpengaruh secara signifikan terhadap pertumbuhan Caulerpa tetapi peranan kedalaman dibutuhkan untuk pertumbuhan Caulerpa, seperti yang diketahui bahwa Rumput laut Caulerpa sebagaimana tanaman khorofil lainnya memerlukan unsur hara sebagai bahan baku untuk proses fotosintesis bagi pertumbuhannya. Burhanuddin (2014), mengemukkan bahwa cahaya merupakan salah satu faktor yang mempengaruhi vegetasi perairan, karena berfungsi sebagai energi untuk proses fotosintesis.

\section{Jumlah Bulatan Caulerpa}

Hasil penelitian menunjukkan bahwa pertumbuhan rumput laut Caulerpa sp. dapat dilihat dari pertumbuhan jumlah bulatan setiap 10 hari. Hasil ini dibuktikan dengan analisis rata-rata pertumbuhan pada setiap perlakuan. Dari hasil analisis ragam (ANOVA) menunjukkan bahwa pengaruh jarak tanam dan kedalaman mempengaruhi pertumbuhan jumlah bulatan Caulerpa sp. secara signifikan dengan taraf 5\%, dan terjadi interaksi antara faktor jarak tanam dan faktor kedalaman pada pertumbuhan jumlah bulatan Caulerpa sp. Pertumbuhan paling tinggi terdapat pada perlakuan jarak tanam $30 \mathrm{~cm}$ dengan kedalaman $50 \mathrm{~cm}$ dengan nilai sebanyak 930,833 bulatan dan 
yang terendah pada perlakuan jarak tanam $40 \mathrm{~cm}$ dengan kedalaman $100 \mathrm{~cm}$ sebanyak 718,667 bulatan, ini didukung karena terpenuhi unsur hara dalam sebulan masa pemeliharaan. Adanya perbedaan jumlah bulatanCaulerpa sp., diduga dipengaruhi oleh unsur hara yang didapatkan diperairan kurang baik seperti gelombang tinggi sehingga menyebabkan Caulerpa sp. yang satu dengan yang lain terbawa arus dan berkumpul menjadi satu. Hal ini sesuai pendapat Yudasmara (2014), yang menyatakan bahwa faktor eksternal seperti keadaan lingkungan fisik dan kimiawi perairan yang dapat menghambat pertumbuhan rumput laut. Faktor fisik sperti $\mathrm{pH}$, suhu, salinitas, dan unsur $\mathrm{N}$ dan $\mathrm{P}$ termasuk unsur kimiawi yang ada diperairan yang mendukung pertumbuhan anggur laut. Disamping itu, semakin banyak jumlah bulatan pada Caulerpa maka pertumbuhannya semakin baik, ini dikarenakan bulatan thalus memiliki fungsi untuk menyerap makanan yang berada diperairan menggunakan sel - sel yang terdapat pada bulatan thalus. Hal ini sesuai dengan pendapat Kurniawan (2018), bahwa rumput laut memiliki thalus sebagai pengganti peran daun, batang dan akar, dimana berfungsi sebagai penyerap makanan melalui sel-sel yang terdapat pada thallusnya.

Jarak tanam dan kedalaman yang berbeda memberikan pengaruh yang signifikan untuk pertumbuhan Caulerpa sp., dan terjadi interaksi antara faktor jarak tanam dan faktor kedalaman secara signifikan terhadap jumlah bulatan Caulerpa sp., karena terdapat perbedaan yang nyata sehingga dilakukan uji lanjut Tukey/BNJ untuk melihat pengaruh antar perlakuan. Uji lanjut Tukey/BNJ pada perlakuan jarak tanam $20 \mathrm{~cm}$ dengan kedalaman

$50 \mathrm{~cm}$ tidak berbeda nyata dengan perlakuan jarak tanam $40 \mathrm{~cm}$ dengan perlakuan kedalaman $100 \mathrm{~cm}$, akan tetapi pada perlakuan jarak tanam $40 \mathrm{~cm}$ dengan kedalaman $100 \mathrm{~cm}$ berbeda nyata pada semua perlakuan sedangkan pada perlakuan jarak tanam $20 \mathrm{~cm}$ dengan kedalaman $100 \mathrm{~cm}$, jarak tanam $30 \mathrm{~cm}$ dengan kedalaman $50 \mathrm{~cm}$, jarak tanam $30 \mathrm{~cm}$ dengan kedalaman $100 \mathrm{~cm}$, dan jarak tanam $40 \mathrm{~cm}$ dengan kedalaman 50 $\mathrm{cm}$, berbeda nyata hanya pada perlakuan jarak tanam $30 \mathrm{~cm}$ dengan kedalaman 100 $\mathrm{cm}$. Menurut Atmajaya (1979) peranan kedalaman terhadap pertumbuhan rumput laut berhubungan dengan stratifikasi suhu secara vertikal, penetrasi cahaya, kandungan oksigen dan unsur hara. Berdasarkan uji yang telah dilakukan untuk pertumbuhan jumlah bulatan didapatkan hasil yang berbeda nyata pada perlakuan dan kedalaman yang berbeda. Hal ini diperkuat oleh Darmawati (2017), bahwa faktor penting yang mempengaruhi pertumbuhan rumput laut tergantung pada intensitas sinar matahari untuk melakukan fotosintesis, dimana melalui proses inilah maka sel-sel rumput laut dapat menyerap unsur hara sehingga memacu pertumbuhan rumput laut.

\section{Kandungan Antioksidan}

Dari hasil analisis kandungan antioksidan Caulerpa sp. (Gambar 5), menunjukkan bahwa perlakuan kedalaman yang berbeda memberikan pengaruh terhadap kandungan antioksidan Caulerpa sp. kandungan antioksidan dari kedalaman yang berbeda mengalami kenaikan dan penurunan nilai kandungan antioksidan. Hal ini dipengaruhi oleh faktor baik pada faktor fisika, kimia dan proses uji kandungan yang dilakukan pada saat uji laboratorium, sehingga dapat disimpulkan bahwa kandungan antioksidan yang 
paling banyak terdapat pada perlakuan kedalaman $50 \mathrm{~cm}$ dengan jarak tanam $20 \mathrm{~cm}, 30$ $\mathrm{cm}$ dan $40 \mathrm{~cm}$, ini menunjukkan bahwa semakin rendah kedalaman pada budidaya maka kandungan antioksidan akan semakin tinggi. Ini berhubungan dengan penetrasi sinar matahari yang dapat masuk ke perairan karena Caulerpa sp. merupakan alga hijau yang banyak mengadung pigmen kloril a dan b. Hal ini sesuai pendapat Kune (2007), bahwakedalaman merupakan salah satu faktor penentu dalam pertumbuhan anggur laut dengan bertambahnya kedalaman penanaman maka penetrasi cahaya yang masuk makin rendah, dan sirkulasi oksigen makin rendah.

Dari beberapa penelitian yang telah dilakukan Caulerpa sp. dapat menghasilkan metabolit sekunder yang berfungsi sebagai antioksidan. Chew et al., (2008) menyatakan bahwa pada perkembangnya, selain sebagai bahan makanan Caulerpa racemosa juga banyak dimanfaatkan untuk keperluan medis karena mengandung antioksidan, Caulerpa racemosa mampu menangkal radikal bebas karena jenis alga ini mengadung asam folat, tiamin, dan asam askorbat. Caulerpa sp. juga mengandung caulerpenin yang menunjukkan bioaktivitas terhadap sel lne manusia dan memiliki sifat antikanker, antitumur, dan antiproliferasi. Hasil penelitian Aryudhani (2007) menunjukkan bahwa anggur laut Caulerpa racemosa mengandung senyawa fenol sebagai komponen non gizi. Komponen ini diduga berfungsi sebagai antioksidan. Menurut Santoso et al., (2002) mengatakan bahwa Caulerpa racemosa yang berasal dari Indonesia dan Jepang mengandung komponen polifenol. Komponen polifenol yang terkandung dalam Caulerpa racemosa adalah katekol, dimana katekol termasuk kedalam jenis antioksidan golongan fenol. Antioksidan golongan fenol merupakan antioksidan yang banyak digunakan karena tidak mengandung racun.Peranan faktor kedalaman dan jarak tanam terhadap kandungan antioksidan rumput laut berhubungan erat dengan penetrasi cahaya, jarak tanam berhubungan dengan arus air yang membawa unsur-unsur hara. Unsur hara merupakan salah satu faktor yang sangat berperan penting dalam mendukung proses fotosintesis untuk pertumbuhan dan kualitas rumput laut. Oleh karena itu untuk menunjang kualitas rumput laut (kandungan antioksidan) diperlukan ketersediaan unsur hara dalam perairan. Illustrimo et al., (2013), menyatakan bahwa proses pertumbuhan rumput laut sendiri sangat tergantung pada intensitas sinar matahari untuk melakukan proses fotosintesis, dimana melalui proses inilah maka sel-sel rumput laut dapat menyerap unsur hara sehingga memacu pertumbuhan harian rumput laut melalui aktivitas pembelahan sel dan akan mempengaruhi kualitas rumput laut. Selain faktor diatas, perbedaan kandungan antioksidan dapat juga disebabkan pada saat pengambilan sampel anggur laut yang digunakan berbeda cabang/thallus untuk uji kandungan antioksidan yang nantinya membuat tinggi dan rendahnya hasil yang di dapatkan.

\section{Kualitas air}

Selama pemeliharaan, nilai suhu berkisar antara 27,4 - 27,5 ${ }^{\circ} \mathrm{C}$. Kisaran suhu yang baik untuk menunjang pertumbuhan rumput laut jenis Caulerpa racemosa berkisar antara 27-32 $\mathrm{C}$ (Fatmawati, 2019). Nilai pH (Derajat keasaman) selama pemeliharaan berkisar antara 6,5-7,8. Hal ini sesuai pendapat Fatmawati (2019), yang 
menyatakan bahwa nilai pH yang sesuai untuk rumput laut yaitu berkisar 6,5 - 8,5, 4 6,4, dan 8,5-9. Selama pemeliharaan, nilai salinitas pada kegiatan budidaya anggur laut berkisar antara 28-29 ppt. Hal ini sesuai pendapat Fatmawati (2019) yang menyatakan bahwa nilai salinitas yang cocokuntuk pertumbuhan rumput laut yaitu 22-34 ppt dan 30-32 ppt. nilai fosfat pada kegiatan budidaya anggur laut sebesar 0,1 mg/l. Hal ini sesuai pendapat Darmawati (2016), yang menyatakan bahwa Kandungan fosfat tidat lebih dari 0,1 ppm, jika dalam air laut terdapat fosfat minimal 0,01 mg/l, maka laju pertumbuhan kebanyakan biota air tidak akan mengalami hambatan. Namun, bila kadar fosfat berada dibawah kadar kritis tersebut (0,01 mg/l), maka laju pertumbuhan sel akan semakin menurun. . Hasil penelitian yang didapatkan pada kegiatan budidaya anggur laut sebesar 0,05 mg/l. Hasil ini sesuai pendapat Putri et al., (2019), menyebutkan bahwa perairan alami umumnya menganndung niitrit sebesar 0,001 mg/l sebaiknya tidak melebihan 0,06 mg/l. Dibandingkan dengan konsentrasi nitrat, konsentrasi nitrit yang terukur jauh lebih kecil. Nilai kecepatan arus yang didapatkan di kegiatan budidaya anggur laut sebesar 2,31-3,70 m/s. Hal ini sesuai pendapat Novianti(2015), bahwa kisaran arus yang baik untuk pertumbuhan rumput laut sebesar 40-40 cm/s. Nilai nitrat yang terukur selama kegiatan budidaya anggur laut sebesar 10 $\mathrm{mg} / \mathrm{l}$. Nilai ini tergolong tinggi untuk pertumbuhan rumput laut karena menurut Suparjo (2008), kandungan nitrat di perairan sebesar 0,09- 3,5 mg/l untuk pertumbuhan rumput laut dalam menyerap nutrien. Tingginya nilai nitrat di perairan inibisa disebabkan oleh masukannya bahan organik yang tinggi dari aktivitas daratan yang dapat berupa erosi daratan maupun limbah rumah tangga, limbah rumah pertanian berupa sisa pemupukan yang terbawa langsung oleh perairan laut atau bisa juga disebabkan oleh kecepatan arus yang terlalu tinggi. Hal ini sesuai pendapat Patty (2015), bahwa adanya kandungan nitrat yang rendah dan tinggi pada kondisi tertentu diperairan dapat disebabkan oleh berbagai fajktor antara lain adanya arus yang membawa nitrat dan kelimpahan fitoplankton.

\section{KESIMPULAN}

Adapun kesimpulan yang didapatkan dalam penelitian ini adalah sebagai berikut:

1. Interaksi antara faktor JT (Jarak Tanam) dengan faktor KD (Kedalaman) mempengaruhi secara signifikan terhadap jumlah bulatan dan signifikan terhadap pertumbuhan mutlak dan pertumbuhan spesifik.

2. Pada uji antioksida Caulerpa sp. bahwa kandungan antioksidan tertinggi diperoleh pada perlakuan jarak tanam $40 \mathrm{~cm}$ dengan faktor kedalaman $50 \mathrm{~cm}$ sebesar $45,57 \%$

\section{DAFTAR PUSTAKA}

Ardiansyah, F., Pranggono, H., \& Madusari, B.D. (2020). Efisiensi Pertumbuhan RumputLaut Caulerpa sp. Dengan Perbedaan Jarak Tanam Di Tambak Cage Culture. Jurnal Pena, 21(1), 1-9. https://doi.org/10.1155/2010/706872. 
Dahlia, I., Rejeki, T.S.S. (2017). Pengaruh Dosis Pupuk Dan Substrat Yang Berbeda Terhadap Pertumbuhan Caulerpa Lentilifera. Journal of Aquaculture Management and Technology, 4(4), 95-100.

Darmawati. (2016). Optimasi Pertumbuhan Caulerpa sp. yang Dibudidayakan Dengan Kedalaman Yang Berbeda Di Perairan Laguruda Kabupaten Takalar. Octopus, Jurnal Ilmu Perikanan, 5, 435-442.

Fatmawati, R. E., Aditya, A. C., \& Susanti, M. (2019). Metode Sebar Di Balai Besar Perikanan Budidaya Air. Prosiding Seminar Nasional, 3(9), 234-241.

Iskandar, S. N., Rejeki, S., \& Susilowati, T. (2017). Pengaruh Bobot Awal Yang Berbeda Terhadap Pertumbuhan Caulerpa lentilifera Yang Dibudidayakan Dengan Metode Longline Di Tambak Bandengan, Jepara. Journal of Aquaculture Management and Technology, 4(4), 95-100.

Ismianti, J., Diniarti, N., \& Ghazali, M. (2018). Pengaruh Kedalaman Terhadap Pertumbuhan Anggur Laut (Caulerpa racemosa) Dengan Metode Longline di Desa Tanjung Bele Kecamatan Moyo Hilir Kabupaten Sumbawa [skripsi]. Program Studi Budidaya Perairan : Universitas Mataram.

Mahmudah, N., \& Nursandi, D.J. (2014). Karakteristik kimiawi rumput laut lokal ( Caulerpa sp .) dan potensinya sebagai sumber antioksidan. Prosiding SEMNAS Pengembangan Teknologi Pertanian, 577-584.

Novianti, D., Rejeki, S., \& Titik, S. (2015). Pengaruh Bobot Awal Yang Berbeda TerhadapPertumbuhan Rumput Laut Latoh (Caulerpa Lentilifera) Yang di Budidayakan di DasarTambak, JEPARA. Journal of Aquaculture Management and Technology, 4(4). http://ejournal-sl.undip.ac.id/index.php/jamt

Patty, S. I. (2015). Karakteristik Fosfat, Nitrat, dan Oksigen Terlarut di Perairan Selat Lembeh,Sulawesi Utara. Jurnal Pesisir dan Laut Tropis. 2(1).

Razai, T. S., Putra, I. P., Idris, F., \& Febrianto, T. (2019). Identifikasi, Keragaman dan Sebaran Caulerpa sp Sebagai Komoditas Potensial Budidaya Pulau Bunguran, Natuna. Simbiosa,8(2), 168. https://doi.org/10.33373/sim-bio.v8i2.2177.

Saptasari, M. (2012). Variasi Ciri Morfologi Dan Potensi Makroalga Jenis Caulerpa Di Pantai Kondang Merak Kabupaten Malang. El-Hayah, 1(2), 19-22. https://doi.org/10.18860/elha.v1i2.1695.

Suparjo, M. N. (2008). Daya Dukung Lingkungan Perairan Tambak Desa Mororejo KabupatenKendal. Jurnal Saintek Perikanan, 4(1), 50-55.

Susilowati, A., Mulyawan, A. E., Yaqin, K., \& Rahim, S. W. (2017). Kualitas Air Dan Unsur HaraPada Pemeliharaan Caulerpa lentilifera Dengan Menggunakan Pupuk Kascing. ProsidingSeminar Nasional, 03, 275-282.

Yudasmara, G. A. (2015). Budidaya Anggur Laut (Caulerpa Racemosa) melalui Media Tanam Rigid Quadrant Nets Berbahan Bambu. JST (Jurnal Sains Dan Teknologi), 3(2). https://doi.org/10.23887/jst-undiksha.v3i2.4481 